\title{
PERAN MANAJEMEN HUMAS DALAM MENINGKATKAN PARTISIPASI MASYARAKAT DI MTSN 2 LAMONGAN
}

\author{
Rahmatulloh \\ Universitas Islam Negeri Sunan Ampel Surabaya | ullohr702@gmail.com
}

\begin{abstract}
Abstrak: Tujuan penelitian ini adalah untuk mengetahui dan mendeskripsikan antara (1) Perencanaan manajemen humas dalam meningkatkan partisipasi masyarakat di MtsN 2 Lamongan. (2) Pelaksanaan manajemen humas dalam meningkatkan partisipasi masyarakat di MtsN 2 Lamongan. (3) Evaluasi manajemen humas dalam meningkatkan partisipasi masyarakat di MtsN 2 Lamongan. Jenis penelitian yang digunakan adalah penelitian kualitatif. Dengan metode observasi, metode dokumentasi dan metode wawancara. Penelitian ini menggunakan teknik analisis data deskriptif kualitatif dengan kata tertulis atau lisan sebagai alat untuk menentukan keterangan mengenai gambaran secara ringkas suatu gejala, peristiwa atau keadaan sehingga dapat ditarik kesimpulan bahwa. Pertama, perencanaan manajemen humas dalam meningkatkan partisipasi masyarakat di MtsN 2 mereka selalu membuat program bersama-sama melalui rapat semua pihak diantaranya kepala sekolah, kabid humas, para guru serta pegawai yang menyusun program bidang lain yang akan dilaksanakan . Kedua, Pelaksanaan manajemen humas sesuai perencanaan dimana tugas humas untuk memberikan pelayanan dan informasi, menyediakan sarana dan prasarana yang memadai. Ketiga, evaluasi manajemen humas merupakan tahap akhir dari pengelolaan humas, dilakukan sesuai standart pelayanan madrasah, dilakukan pihak internal dan eksternal madrasah
\end{abstract} Keywords: Manajemen Humas, Partisipasi Masyarakat

\section{Pemdahuluan}


Pendidikan adalah proses untuk memberikan manusia berbagai macam situasi yang bertujuan memberdayakan diri. Jadi, banyak hal yang dibicarakan ketika kita membicarakan pendidikan. Aspek -aspek yang biasanya paling dipetimbangkan antara lain (a) penyadaran, (b)encerahan, (c) pemberdayaan dan (d) perubahan prilaku.

Berbagai teori dan konsep pendidikan memberikan arti yang berbeda tentang konsep tersebut. Mereka mendiskusikan apa dan bagaimana tindakan yang paling efektif mengubah manusia agar terberdayakan, tercerahkan, tersadarkan dan menjadikan manusia sebagaimana mestinya manusia. Pada titik yang terakhir kita akan menemui berbagai macam pandangan filsafat tentang manusia. Karenanya pendidikan berkaitan dengan bagaimana manusia dipandang dalam hal ini pandangan ilmiah tentang manusia memiliki implikasi terhadap pendidikan. Ini merupakan wilayah studi antropologi pendidikan. Antropologi sendiri merupakan ilmu tentang asal usul, perkembangan, karakteristik, jenis manusia atau studi tentang manusia. Juga banyak aspek lain yang harus kita pahami untuk memahami makna pendidikan. Arti pendidikan itu sendiri juga menimbulkan berbagai macam pandangan, termasuk bagaimana pendidikan harus diselenggarakan dan metode apa yang harus dipakai.

Perkembangan dari pendidikan tidak akan lepas dari partisipasi masyarakat terutama orang tua siswa melalui cara-cara yang demokratis, karena makin tinggi partisipasi makin besar rasa memiliki, makin besar rasa memiliki, makin besar pula rasa tanggung jawab terhadap pendidikan. Untuk menggalang partisipasi masyarakat terhadap lembaga pendidikan maka lembaga memerlukan sebuah manajemen humas yang harus dikelola dengan baik sehingga mempermudah menjalin komunikasai dengan masyarakat dalam rangka meningkatkan partisipasi masyarakat terhadap sekolah. Karena komunikasi merupakan lintasan dua arah, yaitu dari arah sekolah ke masyarakat dan sebaliknya, sehingga secara tidak langsung sekolah harus mampu memfungsikan manajemennya dengan baik, dalam hal ini manajemen yang mengatur hubungan dengan masyarakat, 
baik masyarakat internal maupun masyarakat eksternal, karena manajemen merupakan kebutuhan yang sangat penting bagi peningkatan kualitas pendidikan kedepan dan senantiasa dikembangkan.Sebagaimana dikutip oleh Mulyasa dalam bukunya "Menjadi Kepala Sekolah Profesional" dari pendapat Engkoswara bahwa: Manajemen pendidikan adalah suatu ilmu yang mempelajari bagaimana menata sumber daya untuk mencapai tujuan yang telah ditetapkan secara produktif dan bagaimana mencipatakan suasana yang baik bagi manusia yang turut serta dalam mencapai tujuan yang disepakati bersama. Pendapat di atas menjelaskan, bahwa dalam sebuah lembaga pendidikan mempunyai tujuan-tujuan yang akan dicapai sebagai acuan keberhasilan dalam operasionalisasi kegiatan. Tidak menutup kemungkinan dalam hal ini membutuhkan kejelian dalam merumuskan tujuan yang akan dicapai.

Menurut sejarah, pada awalnya memunculan istilah Manajeme Humas berkenan degan suatu metode public relations saata menghadapi suatu puncak krisis ada tahun 1906. Saat itu terjadi pemogokan total buruh diindustri pertambangan batu bara di Amerika Serikat. Sebagai akbatnya adalah terancamnya keluncuhan total industry batu bara terbesar di Negara tersebut.

Pada titik puncak yang berlangsung tersebut,muncul Ivy Ledbetter Lee (cutlip. Et. Al.2000:116), seorang tokoh Public Relations /Humas pertama, yang berlatar belakang seseorang jurnalis. Beliau mengajukan Manajemen Humas sebagai salah satu solusi atau sebagai jalan keluar untuk mengatasi krisis yang tengah terjadi di industri batu bara di Amerika Serikat sebagai akibat pemogokan massal untuk meminta kenaikan upah.

Untuk memecahkan permasalahan tersebut Ivy Lee mengajukan beberapa usulan atau persyaratan yang bersifat revolusioner dan merupakan terobosan besar dalam peranan PR/ Humas untuk mampu mengatasi masalah besar pada waktu itu melalui suatu konsepsi prinsip-prinsip dasar yaitu:

Pertama, membentuk manajeme humas untuk mengatur arus informasi/ berita secara terbuka. Bekerja sama dengan pihak pers. Duduk sebagai tol pimpinan perusahaan, dan langsung sebagai 
pengambil keputusan tertinggi (decision maker) dan (policy maker). Dalam hal ini Ivy Lee, ditunjuk sebagai Exekutif Assistant to President Director dalam struktur maajemen perusahaan.

Kedua, memiliki wewenang penuh dalam melaksanakan fungsi dan peranan sebagai Pejabat Humas untuk mengelola manajemen Humas/PR. Ketiga, Manajemen Humas, yang notabene terkait dengan manajemen perusahaan industri pertambangan batu bara tersebut harus bersifat informasi terbuka (open communnication), baik kepada khalayak/public, pekerja, mampu pihak pers. Dimana mengacu pada Declaration of principles atau prinsip-prinsip dasar.

Jadi dalam kalimat —Manajemen Krisis dan Humas II tersebut terkandung pengertian tentang kemampuan praktisi Humas (public relations officer) untuk memimpin, melakukan peranan komunikasi dan pengelola saluran informasi (management of communication) demi tercapai pemahaman suatu permasalahan. Terkandung pula kemampuan praktis humas untuk mengatasi krisis (sense of crisis recovery), kepentingan publikasi dan menciptakan citra positif bagi lembaga/organisasi yang diwaklinya itu. Pelaksanaan komunikasi timbal balik antara lembaga/organisasi dan publiknya dilakukan oleh pihak PR/Humas dengan membentuk Manajemen Humas ll baik secara teknis operasional maupun manajerialnya. Oleh karena itu pejabat humas dan stafnya mempunyai tanggung jawab dan wewenang untuk menyusun program acara (special events program \& agenda setting) mulai dari pengumpulan data, definisi masalah, melakukan perencanaan, pelaksanaan, komunikasi hingga mengadakan pengawasan/penilaian hasil yang dicapai baik secara kualitas maupun kuantitas.

Robert Kritiner mendefinisikan manajemen sebagai suatu proses kerja melalui orang lain untuk mencapai tujuan organisasi dalam lingkungan yang berubah. Proses ini berpusat pada penggunaan yang efektif dan efisien terhadap penggunaan sumberdaya manusia. Pendapat tersebut jelas bahwa manajemen sekolah sangat berperan penting terutama manajemen humas, karena suatu sekolah tidak akan

berkembang dengan baik tanpa adanya hubungan yang baik dengan mayarakat. Kenyataan ini menuntut pengelola sekolah 
untuk bersikap rasional dan berorientasi kepada masyarakat luas. Karena pada hakikatnya masyarakat mengharapkan suatu lembaga pendidikan yang berkualitas dan menjanjikan masa depan yang cerah. Manajemen humas merupakan salah satu sarana yang harus ada di suatu lembaga pendidikan, bahkan terbukti saat ini banyak lembaga pendidikan Islam yang dapat berkembang dengan pesat karena pengelolaan manajemen yang sangat baik dan terarah.

Undang-undang Republik Indonesia No. 20 Tahun 2003 Pasal 54 menjelaskan bahwa peran serta masyarakat dalam pendidikan meliputi peran serta perseorangan, kelompok, keluarga, organisasi profesi, pengusaha, dan organisasi kemasyarakatan dalam penyelenggaraan dan pengendalian serta pelayanan pendidikan. Meningkatkan partisipasi masyarakat bukanlah pekerjaan yang mudah karena dalam upaya tersebut memerlukan perencanaan secara terpadu dan menyeluruh. Terkait dengan fungsi pendidikan sebagai salah satu tempat pertemuan masyarakat dalam upaya mempertahankan, mempelajari, dan meningkatkan sosial budaya masyarakat. Hal yang sama juga dilakukan MtsN 2 Lamongan, dalam kegiatan di sekolah maupun di luar sekolah selalu memfungsikan manajemen humas agar kegiatan dapat terlaksana dengan baik, karena secara tidak langsung masyarakat ikut berpartisipasi didalamnya, baik masyarakat internal maupun eksternal. Disamping itu, berdirinya sekolah Islam ini juga diprakarsai oleh masyarakat, karena pada waktu itu banyak pihak orang tua menginginkan sebuah lembaga pendidikan Islam yang berkualitas dan berbasiskan nilai-niai Islam, sehingga masyarakat mengajukan inisiatif ini kepada pihak yayasan agar mendirikan Madrasah Tsanawiyah Negeri 2 Lamongan ini. Dapat dipahami, bahwa partisipasi dari orang tua siswa telah nampak sejak berdirinya sekolah ini. Madrasah Tsanawiyah Negeri 2 Lamongan juga menerapkan pelaksanaan kegiatan pembelajaran mulai dari jam 07:10 sampai 14:10, sehingga antara pihak sekolah dengan pihak orang tua siswa membutuhkan komunikasi dan kerjasama, demi terlaksananya kegiatan pembelajaran dengan baik, dimana orientasinya untuk keberhasilan peserta didik. Kegiatan humas dalam suatu lembaga pendidikan tidak hanya meliputi hubungan 
sekolah dengan orang tua siswa saja, akan tetapi menjalin hubungan dengan masyarakat luas, seperti menjalin relasi dengan masyarakat sekitarnya, dengan sekolah lain, serta instansi pemerintah. Karena dalam pelaksanaan kegiatan pendidikan membutuhkan jalinan komunikasi secara menyeluruh dengan semua lapisan masyarakat, agar supaya keberadaan sekolah sebagai lembaga pendidikan Islam dapat diterima di tengah-tengah masyarakat dan pelaksanaan kegiatannya berjalan dengan efektif dan efisien. Humas juga diartikan sebagai segenap kegiatan dan teknik atau kiat yang digunakan oleh organisasi atau individual untuk menciptakan dan memelihara suatu sikap dan tanggapan yang baik terhadap keberadaan sepak terjangnya. Kegiatan humas yang dilaksanakan di sekolah adalah untuk menjaga hubungan baik dengan semua lapisan masyarakat dan meningkatkan peran aktif dengan masyarakat pula, seperti yang dilakukan oleh Madrasah Tsanawiyah Negeri 2 Lamongan, keberadaan humas akan menguntungkan kedua belah pihak yaitu pengelola pendidikan dan masyarakat. Dengan adanya kegiatan humas akan memancing partisipasi aktif yang positif dari masyarakat, sehingga akan diikuti oleh berbagai bantuan yang datang karena telah terciptanya respons yang baik dari masyarakat, baik dengan dukungan moral maupun material dengan melihat kesungguhan dari pengelola lembaga pendidikan ke arah yang lebih maju

Keterlibatan partisipasi masyarakat pada sekolah sangat penting. Tanpa partisipasi masyarakat, sekolah hanya akan merupakan oraganisasi yang kering dan tidak dapat memenuhi kebutuhan dan tujuan masyarakat. Partisipasi masyarakat memiliki kewenangan dalam segala aspeknya. Selamat. Berdasarkan realita tersebut, Madrasah Tsanawiyah Negeri 2 Lamongan harus dapat mencerna dan menganalisa kebutuhan peserta didik dan masyarakat. Oleh karena itu, keberadaan humas mempermudah untuk mengkaji hal-hal yang berkaitan antara lembaga dan masyarakat demi keberhasilan tujuan pendidikan. Mengingat begitu pentingnya keberadaan humas dalam lembaga pendidikan Islam, maka peneliti mengangkat judul journal tentang "Peran 
Manajemen Humas Dalam Meningkatkan Partisipasi Masyarakat di Madrasah Tsanawiyah Negri 2 Lamongan".

Berdasarkan latar belakang di atas, maka peneliti menarik rumusan masalah tentang manajemen humas dalam meningkatkan partisipasi masyarakat di lembaga pendidikan Islam MtsN 2 Lamongan, diantaranya sebagai berikut:

a. Bagaimana perencanaan manajemen humas dalammeningkatkan partisipasi masyarakat di MtsN 2 lamongan?

b. Bagaimana pelaksanaan manajemen humas dalam meningkatkan partisipasi masyarakat di MtsN 2 Lamongan?

c. Bagaimana evaluasi manajemen humas dalam meningkatkan partisipasi masyarakat di MtsN 2 Lamongan?

Manajemen diidentikkan dengan istilah pengelolaan, pembinaan. Ketatalaksanaan, pengurusan, ketatausahaan, dan ketatapengurusan. Karena seperti yang kita ketahui dalam khazanah ilmu pengetahuan banyak praktisi yang mempunyai persepsi masingmasing tentang pengertian manajemen itu sendiri, namun pada intinya sama. Manajemenen diartikan ilmu, kiat, dan profesi. Dikatakan sebagai ilmu oleh Luther Gulick karena manajemen dipandang sebagai suatu bidang pengetahuan yang secara sistematik berusaha memahami mengapa dan bagaimana orang bekerjasama. Dikatakan sebagai kiat oleh Follet karena manajemen mencapai sasaran melalui cara-cara dengan mengatur orang lain menjalankan tugas. Dipandang sebagai profesi karena manajemen dilandasi oleh keahlian khusus untuk mencapai suatu prestasi manajemen, dan para professional dituntun oleh suatu kode etik. Menurut Paul Hersay dan Kenneth H. Blanchard "Manajemen sebagai suatu usaha yang dilakukan dengan dan bersama individu atau kelompok untuk mencapai tujuan organisasi". Lembaga dalam bentuk apapun memerlukan manajemen untuk menjalankan semua kegiatan yang akan dilaksanakan, sehingga terarah dan mencapai sasaran. Karena dalam suatu kegiatan akan melibatkan banyak orang, dan dalam manajemen itu sendiri membutuhkan kerjasama yang baik. 
Manajemen humas menurut Mc Elreath, adalah: Managing public relations means researching, planning, implementing and evaluating an arry of communication activities sponsored by the organization; from small grup meeting ti internasional satellite linked press conference, from simple brochures to multimedia nasiaonal campaigns, from open house to grassroots political campaign, from public services announcement to crisis management. Manajemen humas berarti penelitian, perencanaan, pelaksanaan dan pengevaluasian suatu kegiatan komunikasi yang disponsori oleh organisasi, mulai dari pertemuan kelompok kecil hingga berkaitan dengan konferensi pers internasional via satelit, dari pembuatan brosur hingga kampanye nasional melalui multimedia, dan menyelenggarakan open house hingga kampanye politik, dari pengumuman pelayanan public hingga menangani manajemen krisis.Hubungan masyarakat adalah fungsi manajemen dari sikap budi yang berencana dan berkesinambungan, yang dengan itu organisasi-organisasi dan lembagalembaga yang bersifat umum dan pribadi berupaya membina pengertian, simpati, dukungan dari mereka yang ada kaitannya atau yang mungkin ada hubungannya dengan jalan menilai pendapat umum diantara mereka, untuk mengkorelasikan, sedapat mungkin, kebijaksanaan dan tata cara mereka, yang dengan informasi yang berencana dan tersebar luas, mencapai kerjasama yang lebih produktif dan pemenuhan kepentingan bersama yang lebih efisien. Manajemen juga dikenal dengan "Rumus $6 \mathrm{M}$ " sebagai singkatan dari Men (Manusia), Money (Biaya), Method (Metode), Machine (Peralatan), Material (Bahan), dan Market (Pasar), yang semuanya merupakan unsur-unsur yang saling berhubungan dalam rangka mencapai tujuan yang telah ditetapkan oleh pimpinan organisasi. Focus kegiatan humas adalah factor manusia.

Merekalah yang harus dibina sehingga bekerja dalam kebersamaan yang harmonis. Dalam pengelolaan manusia untuk menjadi pelaksana yang andal, penguasaan kahumas mengenai teknik-teknik komunikasi menjadi amat penting. Keberadaan humas berperan penting demi di setiap kegiatan sekolah. Dalam bukunya "School Public Relation", Kinred Leslie mengemukakan 
bahwa: hubungan sekolah dengan masyarakat adalah suatu proses komunikasi antara sekolah dan mayarakat dengan tujuan meningkatkan pengertian anggota masyarakat tentang kebutuhan dari praktek pendidikan serta mendorong minat dan kerja sama para anggota masyarakat dalam rangka usaha memperbaiki sekolah. Dilihat dari definisi di atas maka ada 2 kepentingan, (a) Kepentingan sekolah dapat dilihat pemberian informasi dari pihak sekolah kepada masyarakat, sehingga masyarakat membentuk opini tersendiri terhadap sekolah; (b) dilihat dari segi kepentingan masyarakat maka dapat dikatakan bahwa masyarakat dapat mengambil manfaat dan menyerap hasil-hasil pemikiran dan perkembangan pengetahuan dan teknologi yang berguna bagi masyarakat itu sendiri.

Pengertian, penerimaan dan pemahaman masyarakat akan membentuk persepsi masyarakat terhadap sekolah. Elsebree menyatakan, bahwa ada tiga factor yang menyebabkan sekolah harus berhubungan dengan masyarakat (a) Faktor perubahan sifat, tujuan dan metode mengajar di sekolah; (b) Faktor masyarakat, yang menuntut adanya perubahanperubahan dalam pendidikan di sekolah dan perlunya bantuan masyarakat terhadap sekolah (c) Faktor perkembangan ide demonstrasi bagi masyarakat terhadap pendidikan.

Sebagai bagian dari masyarakat, sekolah harus menbina hubungan dengan masyarakat. Di dalam masyarakat banyak kegiatankegiatan yang dilaksanakan oleh kelompok-kelompok masyarakat. Ikut berpartipasi dengan masyarakat merupakan hubungan erat antara sekolah dengan masyarakat. Namun perlu diingat batas-bats kerjasama tersebut sehingga tidak mengganggu dan merusakkan tugas pokok sebagai petugas dan penanggung jawab misi sekolah dan sekolah jangan sampai dieksploitasi untuk kepentingan mereka. Begitu juga sebaliknya hubungan masyarakat dengan sekolah, dilihat dari konsep pendidikan, masyarakat adalah sekumpulan banyak orang dengan berbagai ragam kualitas dari mulai yang tidak berpendidikan sampai kepada yang berpendidikan tinggi. Sementara itu dilihat dari lingkungan pendidikan, masyarakat disebut pendidikan nonformal yang 
memberikan pendidikan secara sengaja dan berencana kepada seluruh anggotanya, tetapi tidak sistematis. Suharsimi Arikunto dalam bukunya menerangkan tentang pentingnya humas dalam pendidikan sebagai berikut, (a) Humas merupakan suatu kegiatan yang sangat diperlukan dalam semua pelaksanaan pekerjaan agar sekolah atau lembaga pendidikan tersebut mempunyai wahana yang resmi untuk dapat berhubungan dengan masyarakat luas serta menunjukkan kepada mayarakat tersebut mengenai kegiatan yang sudah, sedang, dan apa yang akan dikerjakan; (b) Dengan humas sebuah organisasi mempunyai berbagai alat untuk menyebarkan ide atau gagasan kepada organisasi atau badan lain (c) dengan kegiatan humas sebuah organisasi dapat diminta bantuan yang diperlukan dari organisasi atau badan lain; (d) humas mendorong usaha seseorang atau suatu organisasi pendidikan untuk memperkenalkan dan membiarkan diri berhubungan dengan orang atau organisasi lain; (e) Humas memberi kemungkingan bagi seseorang untuk memenuhi kebutuhan didalam mengembangkan diri.

\section{Metodologi}

Pendekatan yang digunakan dalam penelitian ini adalah pendekatan kualitatif dengan rancangan studi kasus. Data dan sumber data pada penelitian ini diperoleh dari data dari hasil wawancara kepada informan, dan data-data lainnya berupa dokumentasi arsip-arsip serta fotofoto yang menunjang data utama. Teknik pengumpulan data pada penelitian ini menggunakan observasi, wawancara dan studi dokumentasi. Teknik analisis data penelitian kualitatif ini dilakukan secara wawancara. Aktivitas dalam analisis data pada penelitian ini adalah reduksi data, penyajian data, dan simpulan. Pengecekan keabsahan data merupakan pembuktian bahwa apa yang telah dialami oleh peneliti sesuai dengan apa yang sesungguhnya ada, serta membandingkan hasil wawancara dari informan satu dan dari informan lainnya. Untuk mengetahui keabsahan data peneliti menggunakan beberapa teknik, yaitu uji kredibilitas yang dengan memperpanjang masa 
penelitian (observasi) di lapangan, meningkatkan ketekunan berarti melakukan pengamatan, triangulasi sumber dan teknik.

\section{Hasil dan Pembahasan}

Perencanaan Manajemenen Humas Dalam Meningkatkan Partisipasi Masyarakat Di MtsN 2 Lamongan Perencanaan manajemen humas merupakan tindakan untuk menetapkan terlebih dahulu apa yang akan dikerjakan, baik menentukan tujuan, sasaran yang akan dicapai sesuai dengan apa yang diharapkan serta program yang akan dilaksanakan. Sebelum melakukan perencanaan, terlebih dahulu akan menganalisis kondisi yang ada di lingkungan pendidikan yang terkait dengan need assessment. Hasil penelitian di MtsN 2 Lamongan menyatakan bahwa dalam membuat perencanaan humas, mereka selalu membuat program atau menyusun program secara bersama-sama melalui rapat dengan semua pihak diantaranya kepala sekolah, kabid humas, para guru serta pegawai yang menyusun program bidangbidang lain yang akan dilaksanakan selanjutnya.

Pelaksanaan Manajemen Humas Dalam Meningkatkan Partisipasi Masyarakat Di MtsN 2 Lamongan Pelaksanaan manajemen humas adalah bagian terpenting dalam pengelolaan manajemen humas sehingga dapat menghasilkan yang terbaik. Di MtsN 2 Lamongan bertugas untuk memberikan pelayanan dan informasi, menyediakan sarana dan prasarana yang memadai, berpenampilan yang Islami dan lain sebagainya yang terlaksana dalam kegiatan sehari-hari di MtsN 2 Lamongan diantaranya, Rapat koordinasi, "jumat bersih" kunjungan ke sekolah lain, halal bi halal, pengajian, promosi, buka bersama dan lain sebagainya. Dengan adanya program dibidang humas diharapkan dapat dijadikan wahana menjalin komunikasi dan memberikan kontribusi yang bermanfaat bagi sekolah dan masyarakat itu sendiri. Sebelum melaksanakan program juga akan dibentuk pelaksana dari program tersebut, hal ini dilakukan agar ada penanggung jawab kegiatan sebagai pengatur jalannya kegiatan.

Evaluasi Manajemen Humas Dalam Meningkatkan PartisipasiMasyarakat Di MtsN 2 Lamongan Evaluasi manajemen 
humas merupakan tahap akhir dari pengelolaan humas setelah melakukan proses perencanaan, pelaksanaan, kemudian evaluasi kegiatan yang dilakukan oleh humas, dimana pada tahap evaluasi ini akan diketahui secara keseluruhan apakah kegiatan humas dapat berjalan dengan baik dan sesuai dengan yang diharapkan, dalam evaluasi juga akan ditemukan faktor-faktor pendukung kegiatan serta faktor penghambat kegiatan, karena setiap kegiatan menginginkan agar kegiatan yang direncanakan dan dilaksanakan dapat terlaksana secara efektif dan efisien, dengan adanya evaluasi yang dilakukan oleh panitian pelaksana kegiatan serta pihak humas itu sendiri dan kepala sekolah akan menjadikan kegiatan yang dilaksanakan saat itu sebagai acuan program selanjutnya untuk lebih baik lagi,baik menjutkan program yang sudah ada ataupun program baru yang akan dilaksanakan oleh periode selanjutnya.

\section{Kesimpulan}

Berdasarkan hasil penelitian di MtsN 2 Lamongan, peneliti dapat mengambil kesimpulan bagaimana pengelolaan manajemen humas di MtsN 2 Lamongan dalam rangka meningkatkan partisipasi masyarakat, diantaranya sebagai berikut:

Perencanaan manajemen humas dalam meningkatkan partisipasi masyarakat di MtsN 2 Lamongan antara lain yaitu melibatkan semua pengelola sekolah Dilaksanakan melalui rapat bersama melalui rapat dengan semua pihak diantaranya kepala sekolah, kabid humas, para guru serta pegawai yang menyusun program bidang-bidang lain yang akan dilaksanakan selanjutnya.

Pelaksanaan manajemen humas adalah bagian terpenting dalam pengelolaan manajemen humas sehingga dapat mengahasilkan yang terbaik. Pelaksanaan humas di MtsN 2 Lamongan bertugas untuk memberikan pelayanan dan informasi, menyediakan sarana dan prasarana yang memadai, berpenampilan yang Islami. Kegiatan yang terlaksana dalam kegiatan sehari-hari di MtsN 2 Lamongan diantaranya, senyum sapa slam, Home visit, School Visitation, kunjungan ke sekolah lain, halal bi halal, promosi, buka bersama dan lain sebagainya. Dengan adanya program dibidang humas diharapkan dapat dijadikan wahana menjalin komunikasi dan 
memberikan kontribusi yang bermanfaat bagi sekolah dan masyarakat itu sendiri. Sebelum melaksanakan program juga akan dibentuk pelaksana dari program tersebut, hal ini dilakukan agara ada penanggung jawab kegiatan sebagai pengatur jalannya kegiatan.

Evaluasi manajemen humas merupakan tahap akhir dari pengelolaan humas setelah melakukan proses perencanaan, pelaksanaan, kemudian evaluasi kegiatan yang dilakukan oleh humas, dimana pada tahap evaluasi ini akan diketahui secara keseluruhan apakah kegiatan humas dapat berjalan dengan baik dan sesuai dengan yangdiharapkan, dalam evaluasi juga akan ditemukan factor-faktor pendukung kegiatan serta factor penghambat kegiatan, karena setiap kegiatan menginginkan agar kegiatan yang direncanakan dan dilaksanakan dapat terlaksana secara efektif dan efisien, dengan adanya evaluasi yang dilakukan oleh panitian pelaksana kegiatan serta pihak humas itu sendiri dan kepala sekolah akan menjadikan kegiatan yang dilaksanakan saat itu sebagai acuan program selanjutnya untuk lebih baik lagi, baik menjutkan program yang sudah ada ataupun program baru yang akan dilaksanakan oleh periode selanjutnya.[]

\section{Saran}

Pada sub ini, peneliti memberikan beberapa saran yang mungkin dapat dijadikan kontribusi serta saran yang membangun bagi MTSN 2 Lamongan sebagai alternativ pembenahan diri terutama dalam bidang humas, saran-saran tersebut diantaranya sebagai berikut:

Kepala bidang humas diharapkan untuk lebih tanggap terhadap informasi terutama kaitannya dengan pendidikan, sehingga dapat memberikan kontribusi yang baik bagi perkembangan lembaga, informasi itu terutama yang up to date, karena bagi sekolah yang maju selalu ingin exis dalam dunia pendidikan tidak mau ketinggalan informasi terbaru.

Manajemen humas yang ada di MTSN 2 Lamongan diharapkan setiap melakukan kegiatan apapun baik sifatnya sederhana atau besarbesaran agar dilakukan pengarsipan dengan baik sehingga 
pembukuannya jelas, dan dapat dijadikan referensi untuk kegiatan selanjutnya. Karena dalam organisasi apapun pengarsipan merupakan bagian terpenting baik berupa tulisan, gambar, dan lain sebagainya, apalagi kegiatan bidang humas banyak hal yang perlu didokumentasikan karena humas itu sendiri mempunyai banyak media dan kegiatan yang dilakukannya.

Program yang dilaksanakan di MTSN 2 Lamongan diharapkan agar lebih baik lagi dari saat ini, mengingat MTSN 2 Lamongan merupakan sekolah unggulan dimana peserta didik juga membutuhkan hal-hal yang lebih baru dan lebih baik lagi, apalagi dengan adanya partisipasi para orang tua siswa yang begitu besar dan sangat antusias pada setiap kegiatan yang dilakukan di MTSN 2 Lamongan untuk perkembangan puta-putrinya.

Segala usaha yang dilaksanakan oleh humas di MTSN 2 Lamongan diharapkan dapat dilaksanakan seoptimal mungkin. Dengan demikian, usaha tersebut dapat dirasakan hasilnya baik sekolah itu sendiri ataupun masyarakat, karema dengan keberhasilan tersebut akan menimbulkan daya tarik tersendiri bagi masyarakat. Dalam pengelolaan humas harus memperhatikan tujuan dan sasaran yang diinginkan, sehingga terarah dan benarbenar memperhatikan proses dari pengelolaan humas (perencanaan, pelaksanaan, dan evaluasi) sesuai dengan prosedur yang dilakukan oleh manajemen humas agar lebih sistematis dan terarah, karena proses yang dilakukan secara sistematis akan membuahkan hasil yang memuaskan bagi semua pihak yang terlibat. Dengan demikian tujuan humas untuk melakukan hubungan yang baik dengan masyarakat internal maupun mayarakat eksternal untuk partisipasi masyarakat dalam mengembangkan lembaga pendidikan Islam dapat dilakukan dengan baik demi menjadikan MTSN 2 Lamongan yang berada di jala. Baiduri Bulan sebagai lembaga pendidikan Islam yang semakin berkembang dan dapat diandalkan dari kualitas yang dimilikinya. 


\section{References}

\section{Books and Articles}

Soyomukti, Nurani, 2010 Teori-Teori Pendidikan klasik Hinga Post Modern, Yogyakarta ,Arrsuzzmedia

Abdul ,Rahmat, 2016 , Manajemen Humas Sekolah, Yogyakarta : Media Akademi

Anggoro, Linggar. 2002. Teori dan Profesi Kehumasan Serta Aplikasinya di Indonesia. Jakarta: PT. Bumi Aksara.

Arikunto, Suharsimi. 2004. Organisasi dan Administrasi Pendidikan Teknologi dan Kejuruan. Jakarta: PT. Raja Grafindo Persana.

Derajat, Zakiyah. 2002. Pendidikan Islam dalam Keluarga dan Sekolah. Jakarta: Ruhama. Djumransjah. 2006. Filsafat Pendidikan Islam. Malang:

Bayu Media Effendi, Onong Uchjana. 2002. Hubungan Masyarakat Suatu Studi Komunikologis. Bandung: PT. Remaja Karya.

E. Mulyasa. 2007. Menjadi Kepala Sekolah Profesional. Bandung: PT. Rosda Karya Offset. Infachrudi, Sekarto dan Soetopo,

Henyat. 2006. Administrasi Pendidikan. Malang: IKIP Malang. Fatah, Nanang. 2006. Landasan Manajemen Pendidikan. Bandung: Remaja Rosdakarya.

Jefkins, Frank. 2002. Public Relation. Jakarta: Erlangga.

Moleong, Lexy. 2002. Metodologi Penelitian Kualitatif. Bandung: PT. Remaja Rosdakarya. Muhaimin, Mujib, Abd. 2004. Pemikiran Pendidikan Islam.

Bandung: Trigenda Karya.

Nata, Abudin. 2003. Manajemen Pendidikan Mengatasi Kelemahan Pendidikan Islam di Indonesia. Jakarta: PT. Prenada Media. Nawawi, Hadari. 2005. Metode Penelitian Bidang Sosial. yogyakarta: Gajah Mada Press. 
Purwanto, Ngalim. 2006. Administrasi dan Supervisi Pendidikan. Bandung: PT. Remaja Rosda Karya.

Rahmadi F. 2006. Public Relation dalam Teori dan Praktek. Jakarta: PT. Geamedia.

Ruslan, Rosady. 2007. Manajemen Public Relations dan Media Komunikasi. Jakarta: Raja Grafindo Persada. 